\title{
GOOD CORPORATE GOVERNANCE DAN RASIO HUTANG PERUSAHAAN
}

\author{
Novi Runiati \\ Tina Sulistyani \\ Universitas Ahmad Dahlan
}

\begin{abstract}
ABSTRAK
The aim of this research is to investigate the influence of corporate governance, and firm size to leverage. Good corporate governance that used in this research is Corporate Governance Perception Indeks (CGPI). The independent variable that use in this research is leverage such as Debt to Total Aktiva and Debt to Total Shareholder Equity. The sample in this research are companies which were listed in Corporate Governance Perception Indeks in the year of 2010-2013 in SWA Magazine of publication. Total sample in this research are 11 companies that selected with purposive sampling method. This research uses multiple regression analysis method to investigate the influence of corporate governance and firm size to leverage. The results of this research indicate that good corporate governance had negative significant influence to debt to total aktiva and total shareholder equity. The firm size had no significant influence to debt to total aktiva and total shareholder equity.
\end{abstract}

Keyword: leverage, quality of good corporate governance, firm's size.

\section{PENDAHULUAN}

Pada era globalisasi seperti sekarang ini dunia bisnis berkembang sangat pesat. Banyak industri-industri baru bermunculan dan tidak mau kalah industri lama pun berusaha keras menciptakan berbagai inovatif untuk dapat bertahan dalam persaingan bisnis. Banyak perusahaan yang akhirnya gulung tikar karena tidak dapat bertahan dalam persaingan. Apa yang dibutuhkan perusahaan untuk dapat bertahan dalam persaingan bisnis pada era sekarang ini? Pendanaan memegang peranan sangat penting bagi suatu perusahaan. Dana yang didapatkan dapat berasal dari dalam maupun luar. Dari dalam berasal dari para pemilik perusahaan ataupun pemegang saham, sedangkan dana dari luar berasal dari hutang.

Perusahaan yang sedang berkembang memerlukan modal yang dapat berasal dari hutang maupun ekuitas. Hutang mempunyai dua keuntungan. Pertama, bunga yang dibayarkan dapat dipotong untuk tujuan pajak, sehingga menurunkan biaya efektif dari hutang. Kedua, pemegang hutang (debtholder) mendapat pengembalian yang tetap, sehingga pemegang saham (shareholder) tidak perlu mengambil bagian laba mereka ketika perusahaan dalam kondisi prima. Namun hutang juga mempunyai beberapa kelemahan. Pertama, semakin tinggi rasio hutang (debt ratio), semakin tinggi pula risiko perusahaan, sehingga suku bunganya mungkin akan lebih tinggi. Kedua, apabila sebuah perusahaan mengalami kesulitan keuangan dan laba operasi tidak mencukupi untuk menutup beban bunga, maka pemegang sahamnya harus menutup kekurangan itu, dan perusahaan akan bangkrut jika mereka tidak sanggup. Terlalu banyak hutang dapat menghambat perkembangan perusahaan yang pada akhirnya dapat membuat 
pemegang saham berfikir dua kali untuk tetap menanamkan modalnya.

Selain dari faktor pendanaan yang besar yang diperlukan oleh perusahaan, untuk dapat bertahan dalam persaingan bisnis, perusahaan juga memerlukan pengelolan manajemen yang baik. Tanpa manajemen yang baik perusahaan tidak dapat menjalankan misinya untuk mencapai tujuan yang ingin dicapainya. Baik tidaknya manajemen yang dijalankan dapat dilihat dari kualitas good corporate governance perusahaan tersebut. Corporate governance sendiri merupakan tata kelola perusahaan yang mengelola hubungan antara berbagai pihak yang berkepentingan terhadap pengelolaan perusahaan.

Dengan penerapan GCG tersebut, paling tidak perusahaan akan mengembalikan dan meningkatkan kepercayaan investor asing untuk menanamkan modalnya di Indonesia. Penerapan GCG pada perusahaan menunjukkan bahwa perusahaan akan melakukan suatu perbaikan dalam pengelolaan perusahaan, transparansi dan akuntabilitas yang lebih baik, serta pertumbuhan yang meningkat. Perbaikan dan peningkatan tersebut akan berpengaruh terhadap nilai perusahaan serta meningkatkan kepercayaan masyarakat (investor) untuk menanamkan modalnya.

\section{REVIEW LITERATUR DAN HIPOTESIS}

\section{Good Corporate Governance dan Corporate Governance Perception Index (CGPI)}

Menurut Salim (1999), good corporate governance dapat diartikan sebagai: Proses dan struktur yang digunakan untuk mengarahkan dan mengelola perusahaan dalam meningkatkan kesejahteraan bisnis dan akuntabilitas korporasi dengan tujuan akhir mewujudkan nilai-nilai jangka panjang pemegang saham sambil memperhitungkan kepentingan stakeholder lain.

Dikatakan sebagai struktur karena mengatur hubungan peran dewan komisaris, direksi, pemegang saham, dan stakeholder lain. Sebagai suatu sistem, GCG melakukan pengecekan dan perimbangan kewenangan atas pengendalian perusahaan yang dapat membatasi peluang pengelolaan yang salah, dan peluang pengelolaan aset perusahaan. GCG juga merupakan suatu proses yang transparan atas penentuan tujuan perusahaan, pencapaian, dan pengukuran kinerjanya (Rahardjo dan Dewi, 2004).

Ira M. Millstein, special advisor on corporate governance to the World Bank yang dikutip dalam Hadad (2003) mengemukakan tiga karakteristik utama GCG, yaitu: (1) Transparancy: the disclosure of relevant financial and operational information and oversight control; (2) Protection and enforceability of the rights and prerogatives of all shareholder; (3) Role of directors in corporate governance: approve business plan, monitoring management's performance.

Good Corporate Governance (GCG) merupakan praktik terbaik yang biasa dilakukan oleh suatu perusahaanyang berhasilyang mengacu pada bauran antara alat, mekanisme dan struktur yang menyediakan kontrol dan akuntabilitas yang dapat meningkatkan economic enterprises dan kinerja perusahaan (Tim BPKP, 2003) serta mendorong perusahaan mendorong penciptaan nilai yang diproksi dengan kinerja masa depan. Praktik terbaik ini mencakup praktik bisnis, aturan main, struktur proses dan prinsip yang dimiliki. GCG merupakan syarat bagi perusahaan untuk mendapatkan kepercayaan bagi investor di pasar modal. Perusahaan dengan corporate governance yang baik akan dapat meningkatkan nilai perusahaan bagi pemegang saham. Hal ini karena visi, misi, dan strategi perusahaan dinyatakan secara jelas, nilai-nilai perusahaan serta kode etik disusun untuk memastikan adanya kepatuhan seluruh jajaran perusahaan, terdapat kebijakan untuk menghindari benturan kepentingan dan transaksi dengan pihak ketiga 
yang tidak tepat, risiko perusahaan dikelola dengan baik dan terdapat sistem pengendalian dan monitoring yang baik (Price Waterhouse Coopers dalam Sayidah, 2007).

\section{Corporate Governance Perception}

Index (CGPI) merupakan program riset dan pemeringkatan penerapan GCG yang diselenggarakan oleh The Indonesian Institute for Corporate Governance (IICG) dan Majalah SWA pada perusahaan publik, Badan Usaha Milik Negara (BUMN), Badan Usaha Milik Daerah (BUMD), Lembaga Keuangan Perbankan dan Non-Perbankan, Lembaga Keuangan Syariah dan Perusahaan Swasta di Indonesia secara tahunan sejak tahun 2001 (www.iicg.org). CGPI bertujuan untuk memicu perusahaan dalam meningkatkan kualitas penerapan GCG. Keikutsertaan CGPI bersifat sukarela dan melibatkan partisipasi aktif perusahaan dan seluruh stakeholder-nya (Tedjakusuma, 2012)

CGPI memberikan penghargaan kepada perusahaan yang telah menerapkan prinsip GCG dengan baik dan sesuai dengan indeks yang telah disusun. Penghargaan ini juga dapat dijadikan sebagai motivator bagi perusahaan lain, sekaligus sebagai indikator (bench mark) dalam menilai GCG di Indonesia, serta menjadikan good corporate governance award sebagai suatu indikator atau standar mutu yang ingin dicapai suatu perusahaan dalam bentuk pengakuan diri dari masyarakat terhadap implementasi penerapan GCG di perusahaan.

\section{Corporate Governance dan Rasio Hutang/ Leverage}

Rasio hutang (leverage ratio), yaitu rasio yang mengukur seberapa banyak perusahaan menggunakan dana dari hutang (pinjaman). Hutang merupakan salah satu sumber pendanaan eksternal yang digunakan oleh perusahaan untuk membiayai kebutuhan dana. Pengambilan keputusan akan penggunaan sumber pendanaan yang bersumber dari hutang harus mempertimbangkan besarnya biaya tetap yang ditimbulkan dari hutang berupa bunga (Michael dan Wijaya dalam Dennys dan Deasy, 2012)

Rasio hutang yang digunakan diproksikan dengan debt to total asset ratio dan debt to total shareholder equity. Debt to total asset ratio yaitu dengan membagi total hutang dengan total aktiva perusahaan. Sedangkan debt to total shareholder equity yaitu dengan membagi total hutang dengan total modal sendiri perusahaan.

Menurut Black dkk (2003) terdapat dua alternatif penjelasan tentang hubungan antara struktur modal dengan kualitas corporate governance suatu perusahaan. Pandangan pertama menyebutkan bahwa perusahaan yang memiliki tingkat hutang yang tinggi dalam struktur modalnya akan cenderung menjadi subjek untuk dikenai pengawasan oleh kreditur yang lebih ketat yang biasanya dinyatakan dalam kontrak hutang yang diibuat. Dengan demikian, perusahaan kurang begitu mementingkan kualitas corporate governance, karena sudah ada pengawasan dari pihak eksternal. Penjelasan tersebut disebut a substitution story.

Alternatif penjelasan yang kedua adalah bahwa kreditur sangat berkepentingan dengan praktik governance dari debiturnya dan memiliki kekuasaan yang lebih besar dibandingkan pemegang saham untuk memaksa perusahaan meningkatkan kualitas corporate governance perusahaan. Penjelasan tersebut disebut sebagai an investor pressure story. Black $\mathrm{dkk}$ (2003) berhasil menemukan adanya hubungan negatif antara leverage dan kualitas corporate governance.

Selain dana dari pemegang saham, manajer perusahaan juga mengelola dana dari kreditur baik yang berasal dari bondholder (pemegang obligasi), perbankan atau pihak lain. Konflik kepentingan antara manajer dan kreditur terjadi dalam hal kebijakan hutang. Konflik ini muncul ketika manajemen mengambil proyek-proyek yang mempunyai risiko lebih besar dari yang 
diperkirakan oleh kreditur. Dalam hal ini kreditur tidak mau dirugikan apabila dana diinvestasikan pada proyek yang berisiko tinggi, karena akan meningkatkan risiko kebangkrutan perusahaan yang pada akhirnya akan mempengaruhi nilai perusahaan dengan menurunnya nilai pasar hutang atau obligasi yang belum jatuh tempo. Sebaliknya jika proyek berisiko tinggi tersebut memberikan hasil yang bagus, kompensasi yang diterima kreditur berupa bunga tidak naik. Ini menunjukkan bahwa hutang dapat menjadikan transfer of wealth dari kreditur ke pemegang saham. Penerapan good corporate governance diharapkan dapat meminimalisasi konflik antara pihak-pihak yang berkepentingan dalam perusahaan. Mekanisme kunci dari kerangka corporate governance meliputi struktur dewan direksi, kompensasi direksi dan kepemilikan manajerial, pemegang saham institusional, auditor, informasi akuntansi dan auditing serta pasar untuk pengendalian perusahaan (Short et. al. dalam Sayidah dan Diyah, 2008).

\section{Hipotesis}

$\mathrm{H}_{1}$ : Kualitas good corporate governance secara signifikan mempengaruhi Debt to Total Aktiva pada perusahaan publik non keuangan yang konsisten masuk dalam pemeringkatan CGPI periode 2010-2013.

$\mathrm{H}_{2}$ : Kualitas good corporate governance secara signifikan mempengaruhi Debt to Shareholder Equity pada perusahaan publik non keuangan yang konsisten masuk dalam pemeringkatan CGPI periode 2010-2013.

\section{METODE PENELITIAN}

\section{Populasi, Sampel, dan Teknik Pengambilan Sampel}

Populasi penelitian ini adalah semua perusahaan yang masuk dalam pemeringkatan CGPI dalam Majalah SWA tahun 2010-2013. Kemudian diambil sampel dengan metode purposive sampling yang menggunakan kriteria tertentu agar relevan dengan tujuan penelitian. Kriteria pengambilan smapel adalah perusahaan publik non perbankan dan lembaga keuangan bukan bank yang konsisten masuk dalam pemeringkatan CGPI (Corporate Governance Perception Indeks) pada kurun waktu tahun 20102013 yang dipublikasikan oleh Majalah SWA, perusahaan yang terdaftar di Bursa Efek Indonesia dan perusahaan yang mempublikasikan Laporan Keuangan pada saat masuk dalam pemeringkatan CGPI tahun 2010-2013 yang dipublikasikan oleh Majalah SWA.

Jumlah keseluruhan populasi sebanyak 59 perusahaan. Melalui kriteria pengambilan sampel dengan teknik purposive sampling diatas tersebut, jumlah sampel yang memenuhi kriteria sebanyak 11 perusahaan. Jadi, jumlah sampel yang diambil dalam penelitian ini sebanyak 11 perusahaan.

\section{Teknik Pengumpulan Data}

Penelitian ini menggunakan data sekunder. Data sekunder yang digunakan dalam penelitian dikumpulkan melalui artikel, jurnal, penelitian terdahulu yang sesuai dengan penelitian. Data skor CGPI perusahaan publik non perbankan dan lembaga keuangan bukan bank untuk tahun 2010-2013 diperoleh dari publikasi majalah SWA. Rasio hutang dan ukuran perusahaan diperoleh dari laporan keuangan yang diperoleh dari website www.idx.co.id.

\section{Variabel Penelitian}

Variabel Dependen

Rasio hutang yang merupakan proksi dari kebijakan hutang adalah variabel dependen. Rasio hutang (leverage ratio), merupakan rasio yang mengukur seberapa banyak perusahaan menggunakan dana dari hutang (pinjaman). Rasio hutang yang dipakai adalah debt to total asset ratio dan debt to shareholder equity ratio. Rumus masing-masing rasio adalah sebagai berikut: 
Debt to total asset ratio $=\frac{\text { Total Hutang }}{\text { Total Aktiva }}$

Debt to total shareholder equity ratio $=\frac{\text { Total Hutang }}{\text { Total Modal Sendiri }}$

Variabel Independen

Skor CGPI (Corporate Governance Perception Indeks) yang merupakan proksi dari kualitas penerapan corporate governance adalah variabel independen. Good corporate governance dapat diartikan sebagai proses dan struktur yang digunakan untuk mengarahkan dan mengelola perusahaan dalam meningkatkan kesejahteraan bisnis dan akuntabilitas korporasi dengan tujuan akhir mewujudkan nilai-nilai jangka panjang pemegang saham sambil memperhitungkan kepentingan stakeholder lain. CGPI merupakan program riset dan pemeringkatan penerapan GCG yang diselenggarakan oleh The Indonesian Institute for Corporate Governance (IICG) dan Majalah SWA pada perusahaan publik, Badan Usaha Milik Negara (BUMN), Badan Usaha Milik Daerah (BUMD), Lembaga Keuangan Perbankan dan Non-Perbankan, Lembaga Keuangan Syariah dan Perusahaan Swasta di Indonesia secara tahunan sejak tahun 2001 (www.iicg.org). CGPI bertujuan untuk memicu perusahaan dalam meningkatkan kualitas penerapan GCG.

Variabel Kontrol

Peneliti juga menambahkan variabel kontrol yaitu ukuran perusahaan yang diproksi denganasetyangdimilikiolehperusahaan. Variabel kontrol merupakan variabel yang dikendalikan atau dibuat konstan sehingga hubungan variabel independen terhadap dependen tidak dipengaruhi oleh faktor luar yang tidak diteliti. Variabel kontrol yang ditambahkan dalam penelitian bertujuan untuk menyempurnakan model regresi sehingga menjadi regresi berganda karena tidak mungkin suatu objek penelitian hanya dipengaruhi oleh satu objek saja. Ukuran perusahaan dijadikan variabel kontrol berdasarkan penelitian yang dilakukan oleh Chung (1993) menyatakan bahwa ukuran perusahaan berpengaruh positif signifikan terhadap rasio hutang perusahaan.

\section{Analisis Data}

Data yang diperoleh dianalisis dengan teknik regresi. Model regresi yang digunakan adalah :

DTA $=a+b_{1}$ GCG $+b_{2}$ SIZE $+e$

DTE $=a+b_{1}$ GCG $+b_{2}$ SIZE $+e$

Keterangan:

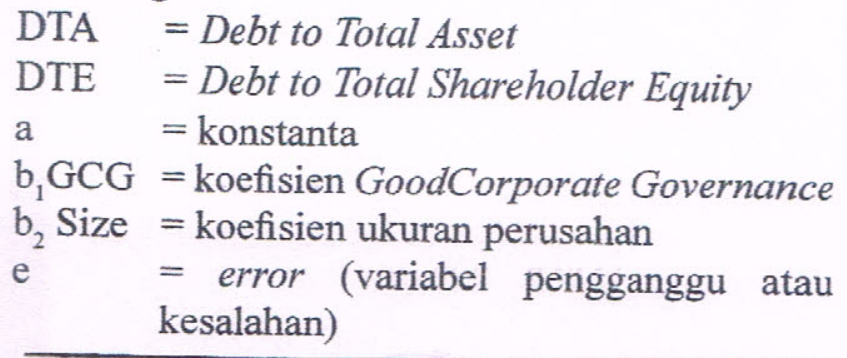

HASIL PENELITIAN DAN PEMBAHASAN

\section{Pengujian Asumsi Klasik}

Hasil regresi dari model Debt to Total Asset (DTA) dan Debt to Total Equity (DTE) keduanya sama-sama menghasilkan model regresi random effect (GLS) sehingga dalam penelitian ini tidak perlu melakukan uji asumsi klasik, karena model regresi sudah bersifat Generalized Least Square (GLS).

\section{Hasil Analisis Regresi}

Debt to Total Asset (DTA)

Berdasarkan hasil analisis regresi diperoleh hasil sebagai berikut:

\section{Tabel 1}

Hasil Analisis Regresi DTA

\begin{tabular}{|c|c|c|}
\hline Variable & Coefficient & Prob. \\
\hline c & 169.8969 & 0.0413 \\
\hline GCG & -4.507118 & 0.0325 \\
\hline SIZE & 0.162194 & 0.7182 \\
\hline R-squared & 0.110018 \\
\hline
\end{tabular}

Sumber : Data sekunder, diolah dengan Eviews 6 
Dari hasil regresi diatas, terlihat bahwa prob. GCG lebih kecil dari alpha yang berarti bahwa variabel GCG berpengaruh signifikan terhadap Debt to Total Asset (DTA) sebesar 0,0325 menggunakan alpha 5\% dengan arah hubungan negatif. Itu artinya semakin besar nilai GCG yang dimiliki perusahaan, maka rasio DTA perusahaan akan semakin kecil. Dan sebaliknya semakin kecil nilai GCG yang dimiliki perusahaan maka rasio DTA perusahaan akan semakin besar.

Variabel SIZE tidak berpengaruh signifikan karena prob. SIZE sebesar 0.7182 lebih besar dari alpha $5 \%$. Itu artinya besar kecilnya asset (SIZE) yang dimiliki oleh perusahaan tidak mempengaruhi besar kecilnya rasio DTA yang dimiliki oleh perusahaan.

Dapat dilihat pula bahwa nilai $\mathrm{R}$ square sebesar 0,110018 atau $11 \%$. Itu artinya bahwa kemampuan variabel independen yaitu GCG dan SIZE dalam menjelaskan variabel dependen (DTA) sebesar $11 \%$, dan sisanya di pengaruhi oleh variabel lain yang tidak digunakan dalam penelitian.

Berdasarkan hasil pengujian yang dilakukan antara variabel GCG terhadap DTA, variabel GCG berpengaruh secara signifikan terhadap variabel DTA dengan arah koefisien negatif. Oleh karena itu, $\mathrm{H}_{1}$ yang menyatakan bahwa kualitas good corporate governance secara signifikan mempengaruhi Debt to Total Aktiva diterima. Arah koefisien negatif menunjukkan bahwa semakin tinggi nilai GCG maka nilai Debt to Total Asset cenderung lebih kecil. Semakin tinggi DTA berarti semakin kecil pembiayaan yang berasal dari asset perusahaan. Hasil penelitian ini konsisten dengan penelitian yang dilakukan oleh Black et.al (2003) yang menyatakan bahwa leverage dan kualitas corporate governance mempunyai hubungan negatif atau berlawanan.
Debt to Total Shareholder Equity Ratio (DTE)

Tabel 2

Model Regresi DTE

\begin{tabular}{|c|c|c|}
\hline Variable & Coefficient & Prob. \\
\hline c & 1236.832 & 0.0575 \\
\hline GCG & -37.27648 & 0.0335 \\
\hline SIZE & 0.119355 & 0.9826 \\
\hline
\end{tabular}

R-squared

0.173633

Sumber : Data sekunder, diolah dengan Eviews 6

Dari hasil regresi diatas, terlihat bahwa prob. GCG lebih kecil dari alpha yang berarti bahwa variabel GCG berpengaruh signifikan terhadap variabel Debt to Total Shareholder Equity (DTE) sebesar 0,0335 menggunakan alpha $5 \%$ dengan arah negatif. Hal ini berarti bahwa Semakin besar nilai GCG yang dimiliki perusahaan, maka semakin kecil rasio DTE perusahaan. Dan sebaliknya, semakin kecil nilai GCG yang dimiliki perusahaan maka semakin besar rasio DTE perusahaan.

Berbeda dengan variabel GCG, variabel SIZE tidak berpengaruh signifikan karena prob. SIZE sebesar 0,9826 lebih besar dari alpha $5 \%$. Itu artinya besar kecilnya asset (SIZE) yang dimiliki perusahaan tidak mempengaruhi rasio DTE perusahaan.

Dapat dilihat pula bahwa nilai $\mathrm{R}$ square sebesar 0,1736 atau $17,36 \%$. Itu artinya bahwa kemampuan variabel GCG dan SIZE dalam menjelaskan variabel DTE sebesar 17,36\%, dan sisanya di pengaruhi oleh variabel lain yang tidak digunakan dalam penelitian.

Berdasarkan hasil pengujian, variabel GCG berpengaruh secara signifikan terhadap variabel DTE dengan arah koefisien negatif. Dari hasil tersebut, maka $\mathrm{H}_{2}$ yang menyatakan bahwa kualitas good corporate governance secara signifikan mempengaruhi Debt to Shareholder Equity diterima. Arah koefisien negatif menunjukkan bahwa semakin tinggi nilai 
GCG yang dimiliki perusahaan, maka semakin kecil nilai DTE yang dihasilkan perusahaan. Semakin kecil nilai DTE menunjukkan semakin kecilnya pembiayaan yang berasal dari ekuitas perusahaan. Itu artinya perusahaan lebih banyak menggunakan pembiayaan yang berasal dari hutang. Hasil penelitian ini juga sesuai dengan penelitian yang dilakukan oleh Black et.al (2003) yang menyatakan bahwa leverage dan kualitas corporate governance mempunyai hubungan negatif atau berlawanan.

Dari kedua model regresi dalam penelitian ini, keduanya menghasilkan pengaruh yang sama yaitu negatif atau berlawanan. Hasil ini menentang adanya bukti bahwa governance yang buruk berhubungan dengan leverage yang lebih kecil (Litov, 2005). Itu berarti bahwa besar kecilnya tingkat rasio hutang perusahaan tidak hanya dipengaruhi oleh hasil penilaian GCG saja, tetapi mungkin ada faktor lain yang lebih berpengaruh.

\section{KESIMPULAN DAN SARAN}

Dari hasil analisis data, pengujian hipotesis, dan pembahasan terhadap terhadap 11 perusahaan sampel dari tahun 2010-2013 dalam penelitian ini maka dapat disimpulkan bahwa: (1) GCG yang diproksikan dengan CGPI berpengaruh signifikan terhadap Debt to Total Asset Ratio dengan nilai signifikansi 0,0325; (2) GCG berpengaruh signifikan terhadap Debt to Total Shareholder Equity Ratio dengan nilai signifikansi 0,0335 ; (3) Untuk variabel kontrolnya yaitu ukuran perusahaan yang diproksikan dengan SIZE tidak berpengaruh signifikan terhadap Debt to Total Asset Ratio karena nilai signifikansi SIZE sebesar 0,7182, (4) SIZE tidak berpengaruh signifikan terhadap Debt to Total Shareholder Equity Ratio karena nilai signifikansi SIZE sebesar 0,9826.

Peneliti selanjutnya diharapkan menambah variabel independen lain yang dimungkinkan memiliki pengaruh terhadap variabel Debt to total Asset (DTA) dan Debt to Total Shareholder Equity (DTE) misalnya Kepemilikan Manajerial, Kepemilikan Institusional, Profitabilitas, dan Kebijakan Deviden. Peneliti selanjutnya juga diharapkan dapat menggunakan seluruh perusahaan yang masuk dalam pemeringkatan CGPI yang dipublikasikan oleh Majalah SWA termasuk Perusahaan Perbankan dan Lembaga Keuangan Bukan Bank.

\section{DAFTAR PUSTAKA \\ Black, Bernard. et. al. 2003. "Does Corporate Governance Predict Firm's Market Values Evidence From Korean", Working Paper.}

Brigham, Eugene F., dan Joel F. Houston. 2001. Manajemen Keuangan. Jakarta: Erlangga.

Chung dan Charoenwong, 1993. "Asset Characteristics and Corporate Debt Policy". Journal of Bussiness Finance and Accounting, hal 83-98.

Farid, Mochammad, dan Kautsar Riza Salman. 2007. "Pengaruh Karakteristik Perusahaan dengan Faktor Regulasi sebagai Variabel Kontrol Terhadap Kualitas Good Corporate Governance Perusahaan". Ventura. Vol 10 No. 2, hal. 1-14.

Fidyati, Nisa. 2003. "Faktor-faktor yang Mempengaruhi Kebijakan Hutang Perusahaan". Jurnal Ekonomi Manajemen dan Akuntansi, Vol. 1, No.1, hal. 17-34.

Hadad, Muliaman D. 2003. "Penerapan Good Corporate Governance di Sektor Perbankan Indonesia". Forum Diskusi Ekonomi BI Putaran 1.

Hart, O. 1995. "Corporate Governance: Some Theory and Implication". Economic Journal. 105, hal. 678-689. 
Harford, Jarrad, et.al. 2005. "Corporate Governance and Firm's Cash Holding, Working Paper". www.ssrn.com.

Husnan, Suad. 2000. Dasar-dasar Manajemen Keuangan. Jakarta: Salemba Empat.

Ismanto, Deni, dan Desta R. K. 2012. Petunjuk Praktikum Eviews. Yogyakarta: Universitas Ahmad Dahlan.

Jensen, Michael C., dan W. H. Meckling. 1976. Theory of The Firm: Managerial Behaviour, Agency Costs and Ownership Structure". Journal of Financial Economics. Vol.3, hal. 305-360.

Kaihatu, Thomas S. 2006. "Good Corporate Governance dan Penerapannya di Indonesia" Jurnal Manajemen dan Kewirausahaan. Vol. 8, No. 1, hal. 1-9.

Litov, Lubomir. 2005. "Corporate Governance and Financing Policy: New Evidence". New York University Working Paper. Maret.

Majalah SWA. 2005. Edisi 09/XXI/28 April-11 Mei.

Majalah SWA. 2010. Edisi 26/XXVI/19 Desember.

Majalah SWA. 2011. Edisi 27/XXVII/19 Desember - 4 Januari.

Majalah SWA. 2012. Edisi 27/XXVIII/20 Desember - 9 Januari.

Majalah SWA. 2013. Edisi 27/XXIX/19 Desember 2013 - 8 Januari 2014.

Martono, dan Agus Harjito. 2003. Manajemen Keuangan. Yogyakarta: Penerbit Ekonisia.

Mutamimah. 2003. "Analisis Struktur Modal pada Perusahaan-perusahaan Non Financial yang Go Publik di Pasar Modal Indonesia". Jurnal Bisnis Strategi II: pp. 71-82. Juli.
Purwandari, Indri Wahyu. 2011. Analisis Pengaruh Mekanisme Good Corporate Governance, Profitabilitas dan Leverage Terhadap Praktek Manajemen Laba (Earning Management). Skripsi. Semarang: Universitas Diponegoro.

Rahardjo, Shiddiq Nur, dan Dewi A. 2004. "Pengaruh Publikasi Penerapan Prinsip Good Corporate Governance Terhadap Harga Saham Perusahaan". Kajian Bisnis. Vol 13 No. 3, hal. 328-344.

Salim, Emil. 1999. "Good Governance dan Masyarakat". Jurnal Transparansi. Edisi 15 Desember.

Sayidah, Nur dan Diyah Pujiati. 2008. "Corporate Governance dan Rasio Hutang Perusahaan". Ventura. Vol. 11, No. 3, hal 299-311.

Surya, Dennys dan Deasy A. R. 2012. "Faktorfaktor yang Mempengaruhi Kebijakan Hutang Perusahaan Non Keuangan yang Terdaftar dalam Bursa Efek Indonesia". Jurnal Bisnis dan Akuntansi. Vol. 14, No. 3, hal 213-225.

Tarjo. 2005. "Analisa Free Cash Flow dan Kepemilikan Manajerial Terhadap Kebijkan Utang pada Perusahaan Publik di Indonesia". Jurnal Riset Akuntansi Indonesia. Vol. 8, No. 1, hal 82-104.

Tedjakusuma, Melissa A. 2012. "Studi Beda Reaksi Pasar atas Pengumuman Corporate Governance Perception Index antara Perusahaan 'Sepuluh Besar' dan 'Non Sepuluh Besar' yang Terdaftar di Bursa Efek Indonesia Tahun 20072011". Jurnal Ilmiah Mahasiswa Universitas Surabaya. Vol. 1, No. 1, hal 1-20. 
Tim Corporate Governance BPKP. 2003. Modul I GCG: Dasar-Dasar Corporate Governance. Penerbit BPKP.

Wafa, S. Azizi, Sulaiman Tahajuddin, dan Ong Fun Aik (2002). "Accountant View of Attributes of Corporate Governance in Malaysian Public Listed Companies". In The Fifth Indinesian Conference on Accountin. Semarang .5-6 September, pp. 87-95.
Wahidahwati. 2000. Pengaruh Struktur Kepemilikan Terhadap Kebijakan Hutang Perusahaan Pada Industri Manufaktur di BEJ. Tesis. Yogyakarta: Universitas Gajah Mada.

Walker, G. and Mark Fox . 2002. "Corporate Gvernance Reform in East Asia". Journal of Corporate Governance. Vol. 2, No. 1, pp.4-9.

Widarjono, Agus. 2009. Ekonometrika Pengantar dan Aplikasinya. Yogyakarta: Ekonisia FE UII. 